\title{
Contributions to our Knowledge of the Species of Utricularia of Great Britain with Special Regard to the Morphology and Geographical Distribution of Utricularia ochroleuca.
}

BY

\section{Professor Dr. H. GLÜCK (Heidelberg).}

With Plates XLVII and XLVIII and seven Figures in the Text.

$\mathrm{T}$ the works ${ }^{1}$ which are at my disposal, the following species are noted as certain :

Utricularia vulgaris, $\mathrm{L}$.

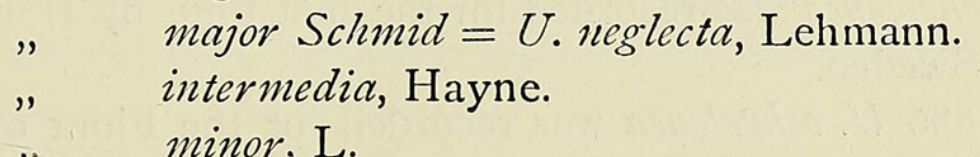

In continental Europe the following species, with the exception of those above named, are found:
Utricularia Bremii.
" ochrolenca.
"exoleta. ${ }^{2}$

U. Bremii and "U. ochroleuca possess a series of stations on the Continent. $U$. exoleta is a tropical type which, however, is only known in one place in Portugal. ${ }^{2}$

U. Bremii is mentioned in Babington's 'Manual', ${ }^{3}$ but it is placed in parentheses, as this species has not been recorded with certainty for the Flora of Great Britain.

As regards $U$. ochroleuca, certain indications and presumptions as to its occurrence in Great Britain are, it is true, to be found in the literature, ${ }^{4}$ but up till now they have received no credence. During the last few years I have visited the British Isles several times to make some special studies

1 J. D. Hooker, The Student's Flora of the British Islands, London, I87o, pp. 297, 298. Charles Cardale Babington, Manual of British Botany, 9th ed., London, 1904. George West, A Further Contribution to a Comparative Study of the Dominant Phanerogamic and Higher Cryptogamic Flora of Aquatic Habit in Scottish Lakes: Proceedings of the Royal Society of Edinburgh, vol. xxx, pt. ii, p. 79 .

2 P. Ascherson, Verhandlungen der Deutschen Botan. Gesellschaft, vol. iv, i 886, p. 404.

3 Charles C. Babington, Manual of British Botany, 9th ed., pp. $33^{8}$ and 339.

4 Compare W. Trail, Annales of Scottish Natural History, I904.

[Annals of Botany, Vo1. XXVII. No. CVIII. October, 1913.] 
touching water-plants. On these occasions I observed, not only that $U$. ochroleuca occurs in Great Britain, but also that in a certain partnamely, in Scotland-it is very widely distributed.

The first clue which led me to $U$. ochroleuca in England was a small and poor example in the herbarium of Oxford University, originating from Loch Mallachi in Scotland. ${ }^{1}$ I visited Loch Mallachi myself in the autumn of last year, and, in spite of the greatest pains, I was unable to find the spot; nevertheless I found the plant a short distance away, in little pools at the road-side not far from a farm between Loch Mallachi and Boat of Garten, and later I discovered a few other places in Scotland and Ireland.

In the following paper I should in the first instance like to communicate to my readers the most important points of the history of the discovery of $U$. ochroleuca; in the second place, its morphological and biological characters will be dealt with in detail; and, in the third place, our present knowledge of the geographical distribution of $U$.ochrolenca will be discussed.

\section{HistoricAl.}

$U$. ochroleuca was recorded for the first time by Hartman ${ }^{2}$ in the year I 857 for Sweden.

In I886 U. ochroleuca was recorded or the Flora of North Germany by $\mathrm{P}$. Ascherson, and since that time it has been found in the following North German provinces: Brandenburg, Pommern, Mecklenburg, Oberlausitz, Schlesien.

In I 893 Utricularia ochrolenca was recorded for South Germany by K. Goebel ${ }^{3}$ (for the Bavarian Highlands), and in 1902 I was myself able to add to this single place a few other South German stations belonging to the heights of the Black Forest. ${ }^{4}$

Besides this, $U$. ochroleuca is mentioned for Galicia by F. Kamienski ; ${ }^{5}$ for Greenland by Joh. Abromeit. ${ }^{6}$ For France it is noted for one place only, viz. for the Vosges Mountains; the plant, originating from a pool near the Lac Longemer and collected by S. Perrin, is identical with the plant of the Black Forest, but as distinguished from this it has copious typical flowers. ${ }^{7}$

1 The Botanical Exchange Club (Report, I9Io, p. 315) has made a communication on this point through G. Claridge Druce, Oxford.

${ }^{2}$ R. Hartman, De Svenska arterna af slægtet Utricularia. Botaniska Notiser, I 857 .

3 K. Goebel, Systematische Gruppierung der deutschen Utricularia-Arten. Mitt. der Bayerischen Botan. Ges., No. 4, München, 1893 .

${ }_{4}^{4}$ H. Glïck, Über die systematische Stellung und geographische Verbreitung der Utricularia ochroleuca. Berichte der Deutschen Botan. Ges., I902, vol. xx.

${ }^{5}$ F. Kamienski, Sur une espèce nouvelle pour la flore du pays (Galicie). Bulletin de l'Académie des Sciences de Cracovie, Déc. 1899, p. 505.

${ }^{6}$ Compare Bibliotheca Botanica, Heft 42, Stuttgart, I899, p. I4I.

7 The plant is to be found in the Herbarium normale of F. Schultz, No. 297 : 'Dans les mares qui avoisinent le Lac de Longemer (Vosges, France) S. Perrin, viii, 1868.' 


\section{MoRPHOLOGY AND Biology of UtRicularia ochroleuCA.}

As $U$. ochrolenca shows the nearest affinity to $U$. intermedia, it will be easily understood that in England $U$. ochrolenca and $U$. intermedia have been until now confused with one another. We must therefore, in the following treatment, also consider $U$. intermedia.

Before entering into the specific differences between $U$. ochroleuca and $U$. intermedia, it is perhaps well to say a few words about the systematic grouping of the European species of Utricularia. It is appropriate here to distinguish the three following natural groups:

(i) U. vulgaris.

$U$. major $(=$ neglecta $)$.

(U. exoleta.)

(ii) U. intermedia.

U. ochroleuca.

(iii) U. minor.

U. Bremii.

$U$.vulgaris and major (neglecta) are the largest indigenous species. The leaves are bipartite and divided into numerous capillary terminal lobes, and bear many bladders. On the base of the flowering stem 'rhizoids' occur; these are small metamorphosed shoots, which serve to anchor the flowering stems and to keep them in a vertical position, but are often rudimentary. ${ }^{1}$ Besides, they produce 'air-shoots'; these are metamorphosed threadlike shoots, which grow upwards to the surface of the water, bearing small scales, and are of service for the exchange of gases. ${ }^{2}$

Utricularia ochroleuca and intermedia are much smaller plants than the two first mentioned. The shoots differentiate in two directions: one kind is covered with green, assimilating floating leaves; the other is colourless and penetrates into the mud. The leaves of the green shoots may be divided into 7-1 5 terminal lobes, and may bear $0-3$ bladders. The 'leaves' of the subterranean shoots are also colourless, and bear on fine filiform branches $3^{-8}$ bladders. 'Rhizoids' are also to be found on the base of the flowering stems, ${ }^{3}$ but the 'air-shoots' are missing.

$U$. minor and $U$. Bremii are the two smallest species, and indeed the latter exceeds the $U$.minor in its general habitat and in the size of its flowers. The shoots also differentiate into green assimilating and colourless underground shoots; the green floating leaves may be divided into 14-20 terminal lobes and may bear $7-8$ bladders. 'Rhizoids' and also 'air-shoots' are missing on the flowering stem.

1 Compare H. Gliick, Biologische und morphologische Untersuchungen über Wasser- und Sumpfgewächse, vol. ii, pp. 66-72.

${ }^{2}$ Compare ibid., pp. $78-83$.

3 In respect of the 'rhizoids' see my above-mentioned work, vol. ii, p. 73. 
We will now go into the specific differences between $U$. ochroleuca and $U$. intermedia. At first we will consider the vegetative organs.

$U$. ochroleuca usually grows in the shallow water of small pools with a boggy bottom (Pl. XLVII, Figs. I and 2, also the forms B, C, D in the table on p. 6I3). The green water-shoots may grow up to $42 \mathrm{~cm}$. in length. With the exception of the underground shoots, which in the first place serve as bearers of bladders in $U$. ochroleuca, the green water-shoots may produce isolated bladders; one or several bladders may be on one shoot (compare

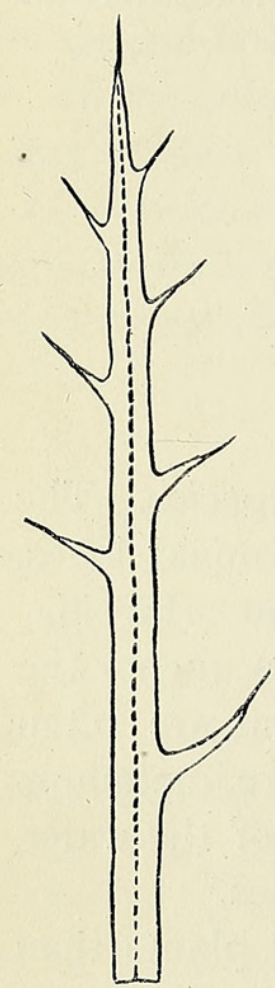

I $a$.

Text-Figs. I $a, b$. Terminal leaf-segments of Utricularia ochroleuca. Fig. I $a$ shows a terminal segment belonging to a Scotch example taken from shallow water, from Boat of Garten. $\times 20$. Fig. I $b$ shows a terminal segment belonging to a Scotch example from deeper water, from the Loch nan Mathair Etive. $\times 20$.

terminal segments (as in the case of the specimens from Loch nan Mathair Etive in Scotland and also of those from Holland), and remind us of the magnificent leaves of $U$. minor (P1. XLVIII, Figs. 17 and I 8). Consequently $U$.ochroleuca is sometimes confused with $U$. intermedia and sometimes interpreted as a hybrid between $U$. intermedia and $U$. minor ${ }^{1}$ which interpretation as hybrid cannot well be defended. We see, on the one hand, that $U$. ochroleuca is normally not associated with $U$. intermedia; on the other hand, we see that in the moors

1 Compare L. M. Neuman, Utricularia intermedia, Hayne, $\times$ U. minor, L. Botaniska Notiser, 1900, p. 65 . 
of Switzerland $U$. intermedia and $U$. minor are often to be found together and flowering at the same time; but in spite of this $U$. ochroleuca is never found in Switzerland. The most marked differences are illustrated by the terminal lobes of the leaves (Pl. XLVIII, Figs. I6-I9). In U. ochroleuca the terminal lobes gradually taper into a point and bear a small spine (see Pl. XLVIII, Figs. $16-18$, and Text-figs. $1 a, b$ ); but in $U$. intermedia the terminal lobes are more or less obtuse and bear also a small spine (see P1. XLVIII, Fig. I9, and Text-figs. $2 a-c$ ). In $U$. ochrolenca the

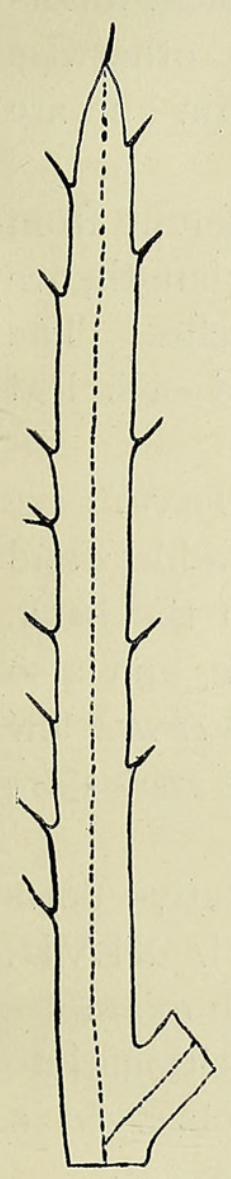

$2 a$.

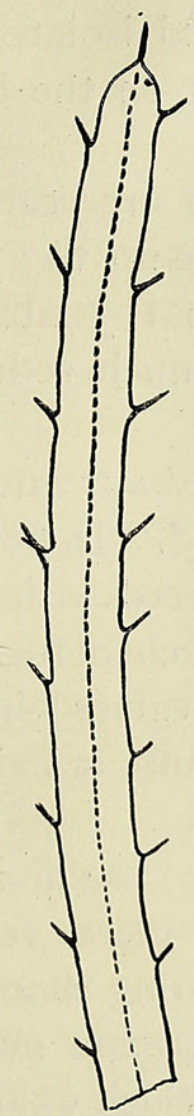

$2 b$.

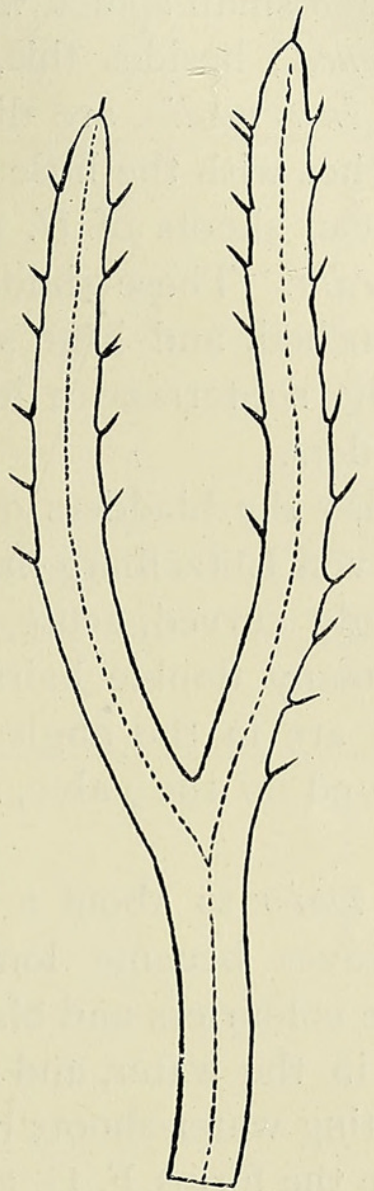

$2 c$.

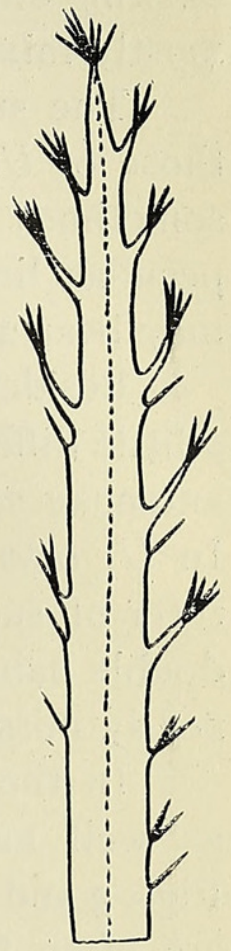

$2 d$.

TeXT-Figs. $2 a-d$. Terminal leaf-segments of Utricularia intermedia. Fig. $2 a$ shows a terminal segment belonging to an example from Switzerland (Wallisellen near Zürich), which was growing in shallow water. $\times$ Iо. Fig. $2 b$ shows a terminal segment belonging to an example from Norfolk. The leaf-apex is more acute than in Fig. $2 a . \times 20$. Fig. $2 c$ shows a terminal segment belonging to an example from Scotland (Perthshire). Fig. $2 d$ shows a terminal segment belonging to an intermediate leaf originating from Norfolk (Barton Turf). $\times 20$.

terminal lobes on each side are furnished with I-6 little spines. In $U$. intermedia the terminal lobes on each side are furnished with from 2-10 spines. In $U$. ochroleuca the little spines are placed in very little and small teeth, but in $U$. intermedia the little spines are placed almost directly on the leaf-edges. In $U$. ochroleuca the little spines are often in pairs, but in $U$. intermedia they are mostly isolated.

It is also not well possible to confuse the typical water-leaves of $U$. ochrolenca with those of $U$. intermedia; they exist through the whole 
summer and autumn in the specimens from continental Europe; but I observed several times in the British specimens of $U$. intermedia, ${ }^{1}$ that in autumn, often before developing the winter bud, a long series of intermediate leaves is formed, which may occupy a length of IO-I $5 \mathrm{~cm}$. of the axis (Pl. XLVII, Fig. 5). Such examples may show a great similarity to $U$. ochroleuca; but on microscopic investigation they can be recognized as belonging to $U$. intermedia. The terminal segments of such leaves are acute, whilst the leaf-edges are denticulate (Text-fig. $2 d$ ). The teeth are furnished with 2-8 small spines, which never occur on the typical waterleaves of $U$. ochroleuca; besides this, small and isolated spines, otherwise existing only in $U$. intermedia, are directly set on the leaf-margin and are mostly mixed together with the little teeth.

The subterranean shoots of $U$. ochroleuca are scarcely different from those of $U$. intermedia. These shoots may be up to $27 \mathrm{~cm}$. in length, are sometimes not brarched, and bear sometimes I-3 lateral branches. The peculiar limb of the subterranean leaves is much reduced, and each leaf may bear $2-4$ bladders.

Besides this also the bladders of $U$. ochrolenca and $U$. intermedia are a little different, as von Lützelburg has recorded. ${ }^{2}$ In both the bladders and antennae are strongly curved, acute, and covered with hairs on the back. In $U$. intermedia many double hairs are attached to the valve, and also tufts of such hairs are in the angles of the valves; in $U$. ochroleuca few double hairs are found on the valve, and the tufts of hairs in the angles are nearly missing.

In the deeper water to about a depth of $100 \mathrm{~cm}$. all vegetative parts as well as the leaves become longer and more tender (Pl. XLVII, Figs. 3 and 4). The colourless and bladder-bearing shoots of such examples are often floating in the water, and show therefore many transitions into green and assimilating water-shoots (Fig. 4). Such examples I observed in different places (see the forms $F, G$, and $H$ in the table on p. 6I 3 ).

$U$. ochroleuca under certain circumstances produces in dry stations land forms which are greatly reduced in all parts, and reach a length of only a few centimetres. I found this only in Germany ${ }^{3}$ (see the form A in the table on p. 6I3).

After having stated the difference of the vegetative region between $U$. ochroleuca and $U$. intermedia, I should like to draw the reader's attention to the fact that $U$. ochrolenca by superficial investigation (viz. without

1 Specimens of such a kind I found myself in pools between Recess Hotel and Recess Station in Ireland; besides this Mr. W. H. Burrell (of Norwich) sent me recently specimens, quite similar, originating from Norfolk, which had been collected in the end of September and in the beginning of October.

2 Compare Ph. von Lützelburg, Beiträge zur Kenntnis der Utricularien. Flora, I909, pp. 63-66, and Figs. $4^{6-48}$.

s Compare H. Gliick, Biologische und morphologische Untersuchungen, \&c., vol. ii, pp. 64,65 . 


\begin{tabular}{|c|c|c|c|c|c|c|c|c|c|}
\hline & 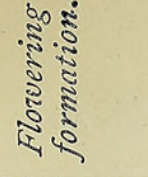 & 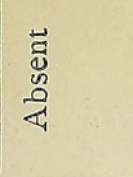 & 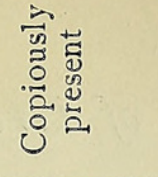 & 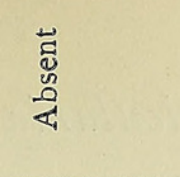 & $=$ & $=$ & $=$ & $=$ & $=$ \\
\hline & 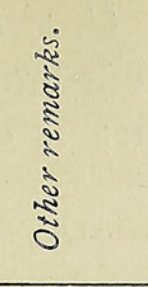 & 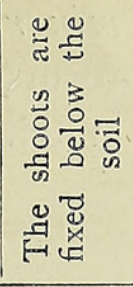 & $=$ & $=$ & $=$ & 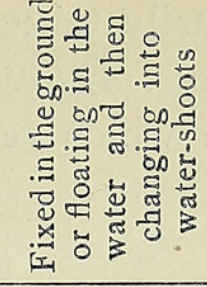 & 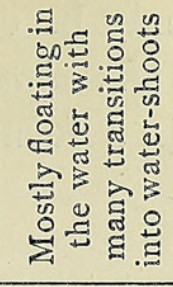 & 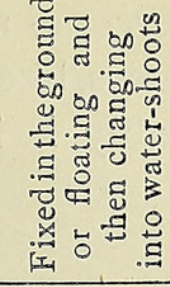 & 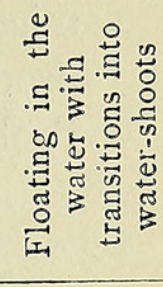 \\
\hline \multirow{3}{*}{ 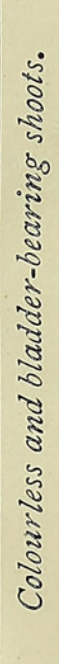 } & 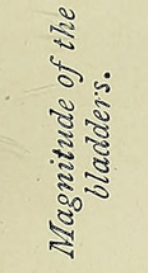 & 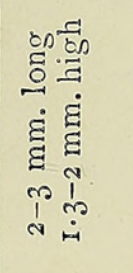 & 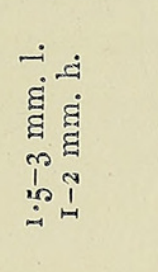 & 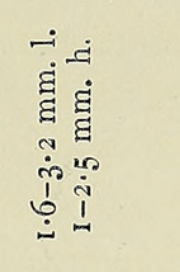 & 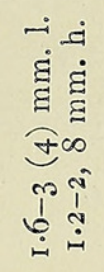 & 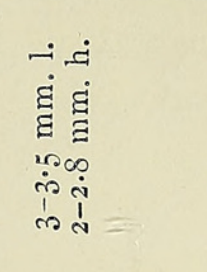 & 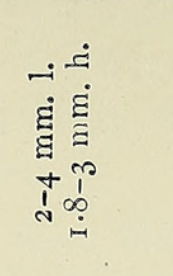 & 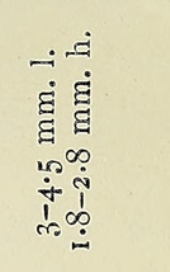 & 1 \\
\hline & 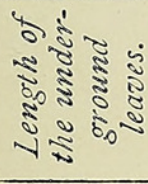 & $\underset{n}{\text { घี }}$ & $\begin{array}{l}\dot{\Xi} \\
\text { a } \\
\Xi \\
\vdots \\
1\end{array}$ & $\begin{array}{l}\dot{g} \\
\Xi \\
+ \\
i \\
\text { in }\end{array}$ & $\begin{array}{l}\dot{E} \\
\text { g } \\
\text { I } \\
\text { in }\end{array}$ & 1 & 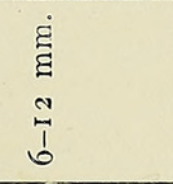 & 1 & 1 \\
\hline & 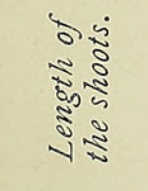 & $\begin{array}{l}\dot{\Xi} \\
\text { ठ } \\
+ \\
\text { I }\end{array}$ & 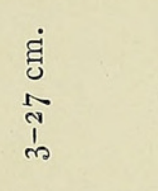 & 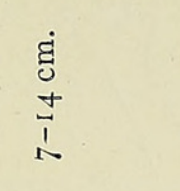 & $\begin{array}{l}\dot{g} \\
\ddot{1} \\
\stackrel{+}{+}\end{array}$ & 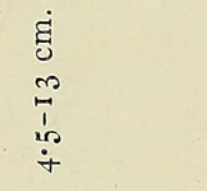 & $\begin{array}{l}\text { घु } \\
\text { in } \\
\text { i } \\
0 \\
0\end{array}$ & $\begin{array}{l}\text { gj } \\
\text { o } \\
\\
a\end{array}$ & $\begin{array}{l}\dot{\Xi} \\
+ \\
\vdots \\
\vdots \\
+\end{array}$ \\
\hline \multirow{3}{*}{ 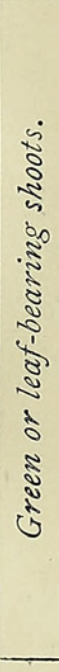 } & 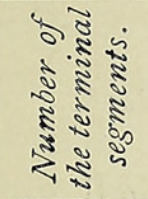 & ì & $\begin{array}{c}\stackrel{a}{1} \\
\overrightarrow{1} \\
0 \\
-\end{array}$ & $\begin{array}{c}\text { à } \\
\text { in } \\
0 \\
1 \\
\text { d }\end{array}$ & $\stackrel{\vec{a}}{a}$ & $\stackrel{I}{I}$ & $\begin{array}{l}0 \\
1 \\
1\end{array}$ & 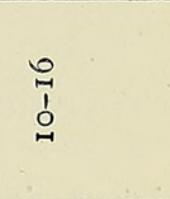 & $\begin{array}{l}\infty \\
1 \\
1\end{array}$ \\
\hline & 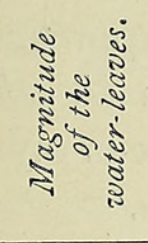 & $\begin{array}{l}\varepsilon \\
\varepsilon \\
20 \\
\dot{1} \\
\stackrel{1}{-}\end{array}$ & $\begin{array}{l}\dot{g} \\
\text { a } \\
i \\
\text { i }\end{array}$ & $\begin{array}{l}\text { घ̇ } \\
\vdots \\
\vdots \\
b\end{array}$ & $\begin{array}{l}\dot{\Xi} \\
\text { घ } \\
\circ \\
\stackrel{1}{1} \\
+\end{array}$ & $\begin{array}{l}\underset{\Xi}{\Xi} \\
\mathbb{E} \\
\vdots \\
\vdots \\
b\end{array}$ & $\begin{array}{c}\dot{g} \\
\vdots \\
\infty \\
0 \\
\vdots \\
0\end{array}$ & $\begin{array}{l}\dot{\Xi} \\
\text { a } \\
20 \\
\vec{I} \\
i\end{array}$ & 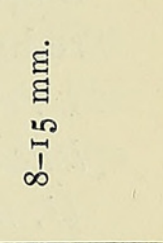 \\
\hline & 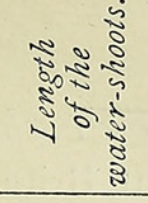 & $\begin{array}{l}\dot{g} \\
\dot{0} \\
0 \\
1 \\
\dot{1} \\
\dot{\text { r }}\end{array}$ & $\begin{array}{l}\dot{घ} \\
0 \\
y \\
\vdots \\
\infty \\
0\end{array}$ & $\begin{array}{l}\dot{\Xi} \\
\infty \\
\tilde{I} \\
\tilde{m} \\
\rightarrow\end{array}$ & $\begin{array}{l}\text { हूं } \\
20 \\
1 \\
\infty\end{array}$ & 1 & $\begin{array}{l}\text { gี } \\
0 \\
0 \\
1 \\
1 \\
2 \\
a\end{array}$ & 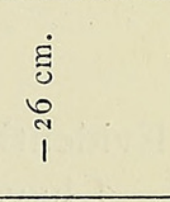 & $\begin{array}{l}\text { gु } \\
\text { ఏ } \\
1\end{array}$ \\
\hline & 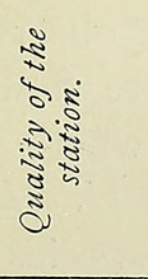 & 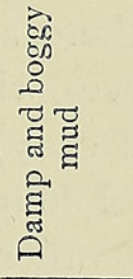 & 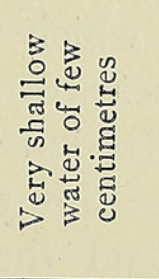 & $=$ & $=$ & 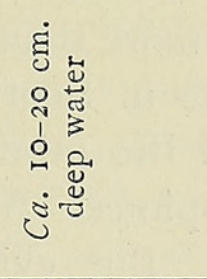 & 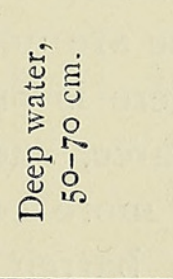 & $=$ & 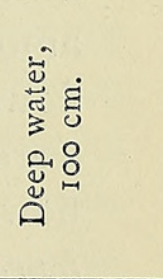 \\
\hline & \multirow[t]{2}{*}{ 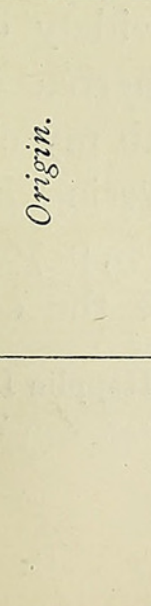 } & 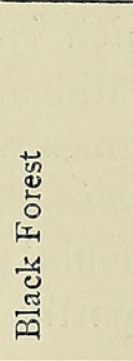 & 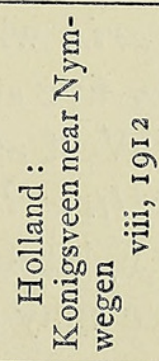 & 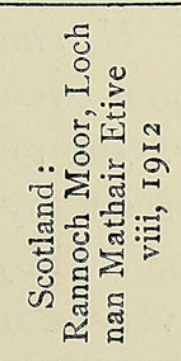 & 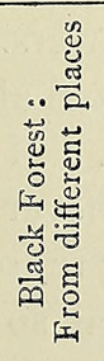 & 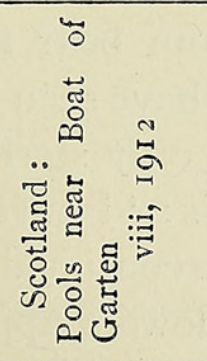 & 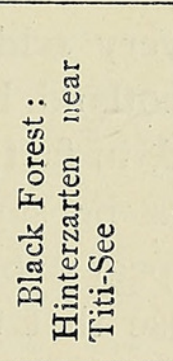 & 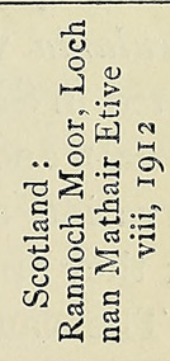 & 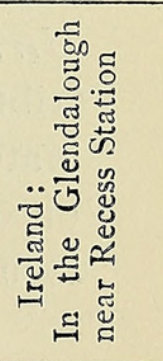 \\
\hline & & 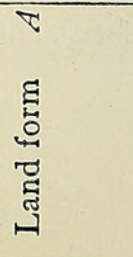 & $\leqslant$ & $\underbrace{u}$ & Q & I & $\overbrace{}^{\text {है }}$ & 0 & 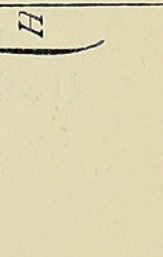 \\
\hline
\end{tabular}


microscope) may be easily mixed up with a form of $U$. minor. $U$. minor produces, like $U$. vulgaris, neglecta, and Bremii, a platyloba-form (Text-fig. 3). Probably it is a form which results from unfavourable nutrition; it dis-

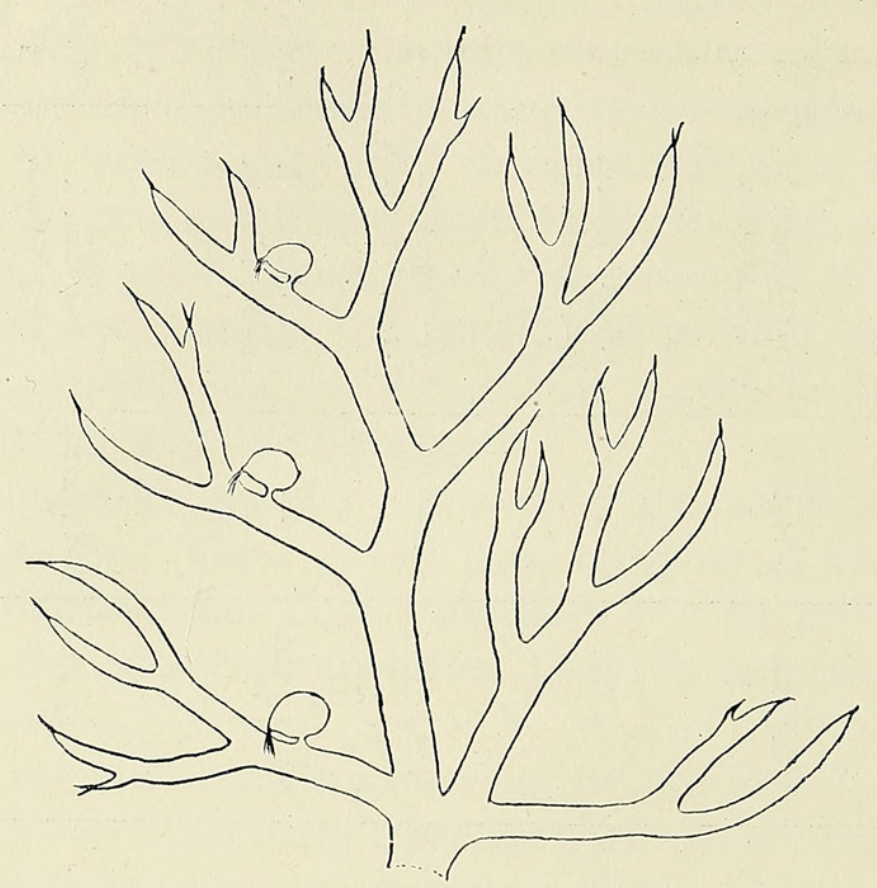

TeXT-FIG. 3. An isolated leaf of Utricularia minor forma platyloba from Scotland.

tinguishes itself from the type by enlarged leaf-segments as well as by reduced bladders. By the pointed end-segments this form approaches $U$. ochroleuca, but by microscopic investigation it differences from $U$. ochroleuca by the absence of the marginal and pricklydenticles. I have seen myself $U$. minor $f$. platyloba in dried state from different Scotch localities. ${ }^{1}$

\section{Flowering Stems.}

Evidently the flowering stems are very rarely developed in $U$.ochroleuca. I have seen $U$. ochroleuca from about fifty stations in Great Britain ; amongst these are no more than two stations on which there are observed flowers. There is one in Scotland (Hillbog, near Garve) where flowers were very scarce, and the other in England (Morden Decoy), where the flowers were more copious. Also in the Black Forest I found U. ochroleuca always barren. But evidently in Scotland the other species of Utricularia very seldom bear flowers. U. vulgaris, which is widely distributed in Scotland, I have seen from about twenty-five stations (herbaceous material), and, in fact, only sterile. Mr. George West agrees with my own observation, as he says: 'I have never seen any Utricularia flowering in a loch; they appear to be continually reproduced by hybernacula' (1.c., p. 79).

The cause that flowers appear so very scarce may partly be the con-

1 For instance : Ardblair Loch (Rattray), Moss of Dalbruzeon (Glenshee), and Happlin Loch (Perthshire). Nat. Hist. Mus. of Perth. 
sequence of the cold stations, partly the strong vegetative propagation with winter-buds, which suppresses the flowering region in consequence of correlation.

The only one station where I found $U$. ochroleuca, and, indeed, with plenty of flowers, is situated in Holland in the so-called 'Konigsveen', not very far from Nymwegen. Mr. H. Höppner, who has occupied himself for many years with the Flora of the Lower Rhine, had the kindness to show me the above-mentioned locality. The following description only refers to the place in Holland.

At the beginning of August we both found $U$. ochrolenca flowering in some ditches of standing and shallow water in which, $U$. ochrolenca excepted, $U$. neglecta and $U$. minor are copiously to be found with flowers. The flowering stems have a height of $10-17 \frac{1}{2} \mathrm{~cm}$. (Pl. XLVII, Fig. I). They produce 2-3 small and sterile scales; at the top stalked flowers emerge from the axil of similar scales, which are very similar to those of $U$. intermedia in size and yellow colour (Pl. XLVIII, Figs. 9-12). The calyx is two-lipped ; the corolla also differentiated into upper lip, lower lip, palate, and spur. The upper lip is ovate and the top obtuse and a little scalloped (height $6.5-7 \mathrm{~mm}$.; width $6-7.8 \mathrm{~mm}$.). The lower lip is rounded, sometimes flat and a little undulated; sometimes the two flank edges are slightly turned down. It is $7-9 \mathrm{~mm}$. long and $\mathrm{I} 2-\mathrm{I} 3 \mathrm{~mm}$. broad when extended in one plane. The palate is globose, depressed, and shorter than the upper lip ; it is furnished with several brownish-red parallel stripes. The spur is conical, about half as long as the lower lip, and almost vertical to the latter; it is about $4-5 \mathrm{~mm}$. long, and tapering towards the top. Fruits are not known to me up till now.

The flowers of $U$. intermedia (P1. XLVIII, Figs. $13-15$ ) are similar to those of $U$. ochroleuca, but are easily to be distinguished; they are, on the average, larger than those of $U$. ochroleuca. The lower lip is longer in proportion to the palate, which is a little scalloped and bears some darkbrown and irregular stripes. The best distinguishing mark is with reference to the spur: it is narrow, cylindrical, and runs parallel to the lower lip; it is sometimes nearly of the same length as the lower lip, sometimes shorter than the latter. The spur of U. ochroleuca, on the contrary, is more conical, about half as long as the lower lip, and nearly vertical to the latter (compare Fig. 9 with Fig. I3, and Fig. I2 with Fig. I5).

'Rhizoids ' occur also here, but I could not find more than one on the base of the flowering stem (P1. XLVII, Figs. 6-8). They can be isolated or exist together with an underground shoot (as in Fig. 6), arising from the base. In many examples the 'rhizoids' seem to be absent, but they existed originally and were later metamorphosed into underground shoots (compare the underground shoot $\mathrm{s}_{1}$ in Fig. I, Pl. XLVII). The 'rhizoids' may have a length of $5-8.5 \mathrm{~cm}$. and bear several (up to seventeen) small lateral 
organs, which become $0.5^{-2.5} \mathrm{~mm}$. long ; the latter are identical with metamorphic leaves (P1. XLVII, Figs. 7 and 8 ); they are pinnatifid in $3^{-1} 2$ large and linear segments, which are twisted in a claw-like manner, their surface nearly vertical to the rhizoid axis. The apices of the lobes are obtuse, furnished with a little spine and densely covered with globose papillae. I observed a great many intermediate forms between the 'rhizoids' and the underground shoots. The underground shoot $S_{1}$ in Fig. I (Pl. XLVII) is originating from a former rhizoid, and the two little segments $(l, l)$ are former rhizoid segments.

The rhizoids of $U$. intermedia are not very different from those of $U$. ochroleuca, but they have mostly more delicate lateral segments, which are without little spines on the apex of the segments. ${ }^{1}$

\section{Propagation and Hibernation.}

Similarly to the other Utricularia species, U. ochroleuca produces also in autumn winter-buds, which serve for the vegetative propagation and hibernation. I found these in August, but only scantily, in two Scotch localities (near Boat of Garten and in the Loch nan Mathair Etive of the Rannoch Moor). On the other hand, formerly I was able to study it minutely with German specimens. ${ }^{2}$ I will only mention the most important points here.

The formation of the buds takes place chiefly in September and October, and can occur as well on the green floating shoots as on the underground shoots. Some intermediate leaves lead over to the development of the winter-bud. In comparison to the vegetative leaves the intermediate leaves grow smaller and smaller, and the edges show a numerous formation of little teeth covered with fasciculated spines.

The buds themselves are globose, $3-5 \mathrm{~mm}$. thick; ${ }^{3}$ they are similar to those of $U$. intermedia, with a covering of hair, which, however, is not so dense as that of $U$. intermedia.

In the germination, ${ }^{4}$ which commences in May or at the beginning of June, the axis-bud expands three to five times its original length, whilst with $U$. intermedia the axis-bud does not experience a secondary prolongation. The typical bud-leaves are in the outline semicircular to reniform, and are divided similarly to the vegetative leaves, but they have terminal lobes greatly shortened and enlarged, of which there may be 7-20. The edge of

1 Compare H. Glïck, 1.c., vol. ii, pp. 73 and 74 .

${ }^{2}$ Compare ibid., pp. 125-I 27.

${ }^{3}$ In land forms the winter-buds are only $\mathrm{I} \cdot 2-2 \mathrm{~mm}$. thick.

4 The germinating winter-buds are not very rare among the herbarium material. I have seen them in Mr. Bennett's herbarium, originating from the following places : from Ben Lawers ; from Moidart (Senn Bowald); from Inverness (Loch an Feidh a Maadaith); in the herbarium of the British Museum from W. Sutherland (Sennie) and from Perthshire (Coninish Valley); in the herbarium of the Nat. Hist. Museum of Perth from the Loch na Craige. 
the terminal leaves bears $2-7$ little teeth, each of which has a tuft of spines. The bud-leaves of $U$. intermedia are similar, but they have broader and more ovate terminal lobes. With $U$. ochroleuca the bud-leaves are followed by several intermediate leaves, which are a transitory form, leading to the typical leaves; out of the axil of the bud-leaves and intermediate leaves underground shoots may come out, which immediately anchor the plant.

I have always found $U$.ochroleuca sterile in the German stations of the Black Forest, in spite of observations extending over several years. The propagation and hibernation is consequently founded, in the first place, on winter-buds. The conditions apparently are the same in Great Britain. In August I found only sterile specimens, when the plant should have flowered. We can assume that not only with $U$. ochroleuca, but also with many other water-plants, the fructificative region is suppressed in consequence of the bud-formation.

\section{Geographical Distribution of Utricularia ochroleuca in GREat BRitain.}

Up to the present I have found $U$.ochroleuca living in the following stations :

In Scotland: In small pools on a roadside between Boat of Garten and Loch Mallachi.

In different places in the Rannoch Moor (Argyle): (a) Loch nan Dubh, (b) Loch nan Mathair Etive, $(c)$ in little pools between the Kingshouse Inn and the farm Tighe Craighe-duible.

In Ireland I found them very isolated in deep water (about $100 \mathrm{~cm}$.) of the Glendalough (near Recess) mixed with Eviocaulon, Isoetes lacustris and echinospora, Pilularia, and Lobelia.

As $U$. ochroleuca is also easily to be recognized in a dry condition, I have made a microscopic examination of the material of four English herbaria :

I. From the private herbarium of Mr. Edward S. Marshall at West Monkton near Taunton (Somerset).

2. From the private herbarium of Mr. Arthur Bennett at Croydon (London).

3. From the herbarium of the British Museum.

4. From the herbarium of the Natural History Museum at Perth.

By far the most copious material I found in Mr. Bennett's herbarium and in that of the Natural History Museum at Perth.

On the basis of this investigation the geographical distribution of $U$. ochroleuca takes the following form: 


\section{Scotland.}

Sutherland: Near Sennie, W.S. (British Mus.); near Inch-na-damph, W.S.; Badcall, W.S. ; pools, moorland of Loch Hope, W.S.; below the east side of Inisay at about I,000 feet (Marshall's Herb.); Loch an Arniboll (Bennett's Herb.).

Ross and Cromarty: Hillbog, near Garve, at about 900 feet, flowering very sparingly (Marshall's and Bennett's Herb.; British Mus.); Loch Kinellan near Strathpeffer, E.R. (Bennett's Herb.).

Inverness: Heath pool at I,000 feet, Senn Bowald in Moidart (Bennett's Herb.; British Mus.) ; pool near Dalwhinnie, NW. side of Loch Ericht, E.I. ; pond near Dorlin in Moidart (Bennett's Herb.); Loch an Feidh a Maadaith and Loch Aline, near Kincraig (Bennett's Herb.).

Perth: Moorland above Crianlarich (Marshall's Herb.); watershed of Coninish Valley (British Mus.) ; Ben Lawers at 3,200 feet (Bennett's Herb.); Loch Broom ; Loch of the Lowes (Dunkeld); Loch Lubnaig; near Loch Skiach (Breadalbane); Dalnaspidal; loch near Meall Cuachlar (Killin); Loch na Craige (Nat. Hist. Mus. at Perth).

Argyll: Pools and lochs of Rannoch Moor near Kingshouse (Marshall's and Bennett's Herb.; British Mus.); in a peaty pool near Kingshouse at foot of Stab Dearg (British Mus.); Loch Laidon, Rannoch Moor (Nat. Hist. Mus. at Perth).

Dumbarton: Loch Sloy, Glensloy base of Benvoiloch (Bennett's Herb.).

Wigton: Near Port Patrick (Bennett's Herb.).

Kirkcudbright: Loch Un and Caldoch Moor (Bennett's Herb.).

Dumfries: Loch Urr and Glencairn parish (Bennett's Herb.); Glencairn (Girrharrow) (British Mus.).

\section{England.}

North Lancashire: Coniston Lake, growing in water 6-Io feet deep (Marshall's and Bennett's Herb.; British Mus.).

Dorset: Talbot Heath, Bournemouth (Marshall's Herb.); Morden Decoy, with flowers (Marshall's and Bennett's Herb.).

Westmorland: In a small pool on the watershed between Easdale and Langdale (Bennett's Herb.).

\section{Ireland.}

Kerry: Shallow peat-pools in the Cumm-een-duffim, in several places, but never with flowers (British Mus.).

Donegal: Pool Doocharry Bridge (Bennett's Herb.).

Shetland 1sles.

Dunrossness: Pools by Loch of Spiggie (Marshall's Herb.); Loch Brue (Bennett's Herb.). 
Hebrides Isles.

Outer Hebrides: North Uist (British Mus.).

Inner Hebrides: Pool near Broadford on Skye; Isle of Islay; east of Loch Fada on the Isle of Colonsay; Isle of Coll ; Isle of Tiree (Bennett's Herb.).

As final result the following emerges from the above compilation:

$U$. ochroleuca is a plant widely distributed in Great Britain and the islands about it. The centre of distribution is in Scotland; no territory of Europe can show so many stations for U. ochroleuca as Scotland. And if from its geographical distribution we consider the conditions of its station the following results: $U$. ochrolenca is a plant adapted to a cold climate, as the Scotch Highlands typically yield, and for that reason $U$. ochroleuca has its chief distribution in Scotland, for which I have indicated about forty localities. On the other hand, $U$. intermedia is a plant adapted to a much warmer climate, and is wont to inhabit low-lying swampy land. $U$. intermedia is therefore not a very rare plant in warm or temperate West Ireland ${ }^{1}$ and in the lowlands of England, and there takes the place of $U$. ochroleuca, but in Scotland it is a very rare plant. In fact I could cite $U$. intermedia only for four Scotch places, belonging to Forfarshire and Perthshire : (I) for Rescobie, near Forfar (British Mus.); (2) for Kinclaren (Devonian Perth); (3) for the curling pond, Meurton Wood (Rattray) ; (4) for a marsh on the east side of Alyth (Nat. Hist. Mus. at Perth).

May this small essay be the means of directing the interest of the English botanists to this up to now neglected water-plant.

To all those who have helped me in the preparation of this article I wish to render here my special thanks; above all to Mr. Edward S. Marshall (Taunton), to Mr. Arthur Bennett (London), to Dr. A. B. Rendle, Keeper of the Herbarium of the British Museum, and to Mr. M. Rodger (Perth).

\section{EXPLANATION OF THE FIGURES IN PLATES XLVII AND XLVIII.}

Illustrating Professor Gliuck's paper on Utricularia.

PLATE XLVII. Figs. I-8.

Fig. I. A form of the shallow water from the Konigsveen in Holland. The horizontal green water-shoot bears water-leaves on which here and there isolated bladders occur; besides which two colourless underground shoots $\left(s_{1}\right.$ and $\left.s_{2}\right)$ are present, the 'leaves' of which all bear bladders. Shoot $\mathrm{S}_{1}$ is originating from a former rhizoid; the little segments $l, l$ are former rhizoid segments. The flowering stem is furnished with two flowers and three barren scales $(=s)$. Nat. size.

1 I myself found the true $U$. intermedia in pools between Recess Hotel and Recess Station, near Ballynahinch, and in the Craigga Moor near Roundstown (Connemara). 
Fig. 2. Another form of shallow water from the Loch nan Mathair Etive on the Rannoch Moor in Scotland. This form is very similar to that of Fig. I. Nat. size.

Fig. 3. A floating form growing in deeper water. The internodes of the green water-shoots are elongated and the leaves are longer and more tender than in Figs. I and 2. Two isolated bladders are visible on the water-shoot. The two colourless shoots show the tendency to change into water-shoots. From the Loch nan Mathair Etive in Scotland. Nat. size.

Fig. 4. A magnificent form, which floated in moderately deep water; the horizontal water-shoot bears three isolated bladders. The two vertical shoots represent, as they are not fixed in the mud, a transition to water-shoots. From little pools near Boat of Garten. Nat. size.

Fig. 5. A water-shoot of $U$. intermedia bearing a winter-bud at the top, whilst its axis is covered with many intermediate leaves, the terminal segments of which are distinctly denticulated. From Norfolk (Barton Turf). Nat. size.

Figs. 6-8. Rhizoid formations.

Fig. 6. Base of the flowering stem with a very long rhizoid of $U$.ochroleuca, originating from the Konigsveen in Holland. $\mathrm{R}=$ rhizoid ; $\mathrm{S}=$ dissected subterranean shoot ; $\mathrm{w}=$ water-shoot ; $\mathrm{F}=$ flowering stem.

Fig. 7. A lateral segment of the middle region of the same rhizoid; it is repeatedly furcate and terminates in eight bent and papillous terminal segments. $\times 20$.

Fig. 8. A very little segment coming from the highest region of the rhizoid, and which terminates in three papillous segments. $\times 20$.

PLATE XLVIII. Figs. 9-I9.

Fig. 9-12. Flower-forms of $U$. ochroleuca.

Fig. 9. Illustrates a flower, side-view ; the spur $(s)$ is to be seen conspicuously; the lower lip is rather flat. $\times 4$.

Fig. 10. Also illustrates a side-view; the lower lip is slightly curved in saddle-form, the spur therefore being covered. $\times 4$.

Fig. II. A front-view of the flower; before the upper lip the globose palate is visible; the lower lip is rather flat, and below this the spur can be seen. $\times 4$.

Fig. 12. Gives a view of the flower from underneath. The spur appears as a prolongation of the upper lip and overlaps the entrance to the palate; the two-lipped calyx is visible from below. $\times 4$.

In all figures $k=$ calyx ; $o=$ upper lip; $u=$ lower lip ; $p=$ palate $s=$ spur.

Fig. I $3^{-I} 5$. Flowers of $U$. intermedia.

Fig. I3. Illustrates a lateral view of the flower. The lower lip is slightly curved in saddle-form and therefore covers the spur, the point of which, however, penetrates below.

Fig. 1 4. Front side of the flower. Through the tender-and in consequence of the action of the alcohol-now transparent lower lip the spur can be faintly seen; the palate is scalloped a little at the top; the two anthers are visible in the form of two little dark spots.

Fig. 15. Demonstrates a flower from below. The long spur appears also here as a continuation of the upper lip, and projects over the entrance to the palate; the lower lip is slightly curved downwards.

Figs. $1^{-15}$ are $\times 4$. The flowers originate from Wallisellen near Zürich (Switzerland); $k=$ calyx $; o=$ upper lip $; u=$ lower lip; $p=$ palate $; s=$ spur.

Fig. 16. A leaf of $U$. ochroleuca, furnished with a bladder. From shallow water near Boat of Garten (Scotland). $\times 4$.

Fig. I7. A bladderless and very richly branched water-leaf of $U$. ochroleuca, originating from shallow water. From the Loch nan Mathair Etive. $\times 4$.

Fig. I8. A leaf furnished with a bladder, originating from a floating form of deeper water. From the Loch nan Mathair Etive. $\times 4$.

Fig. 19. A water-leaf of $U$. intermedia bearing a bladder on the lower rigbt side. From Norfolk (Honing, East Norfolk). $\times 4$. 
Annals of Botany,

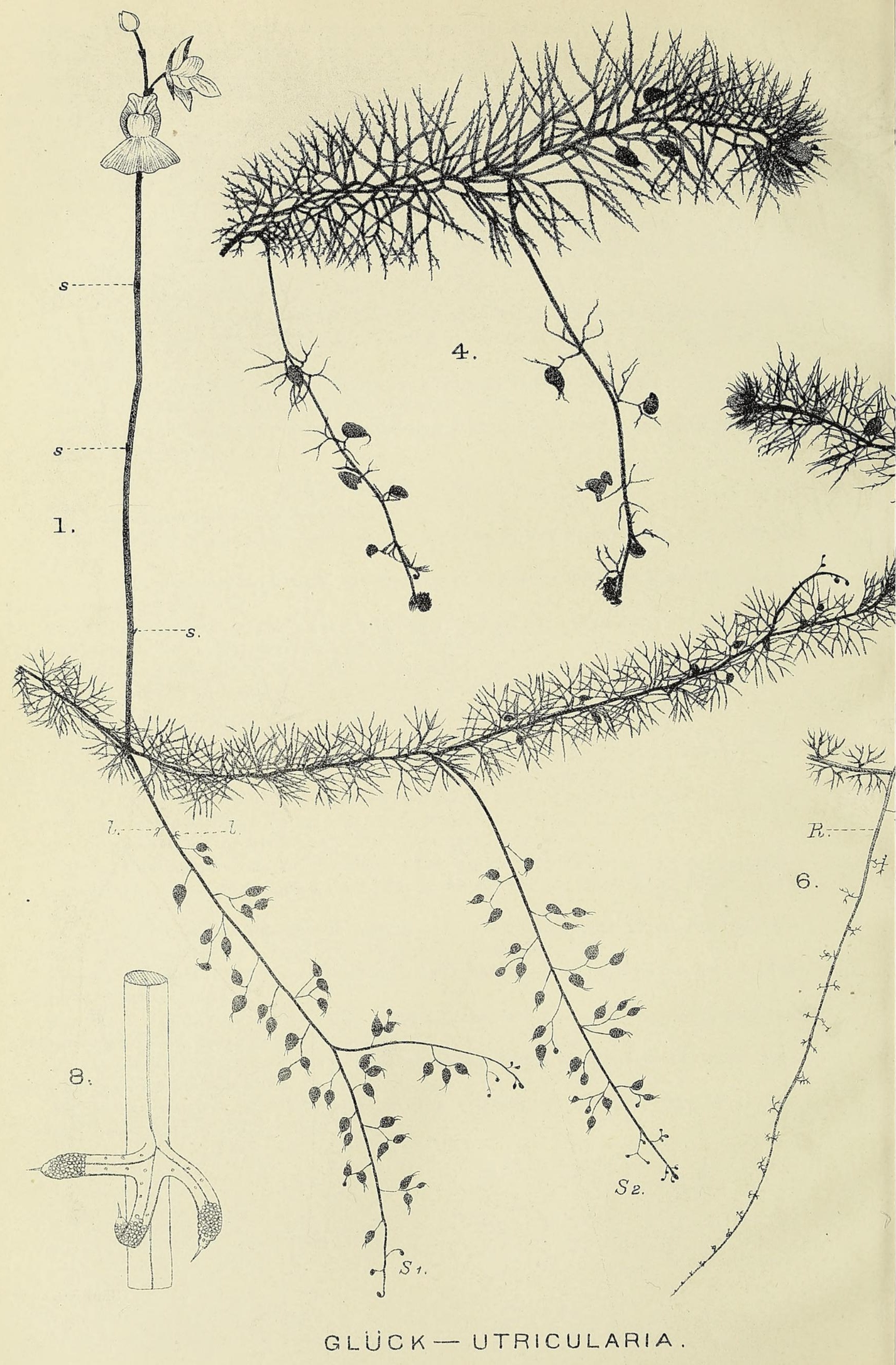




\section{4. \\ $+$}

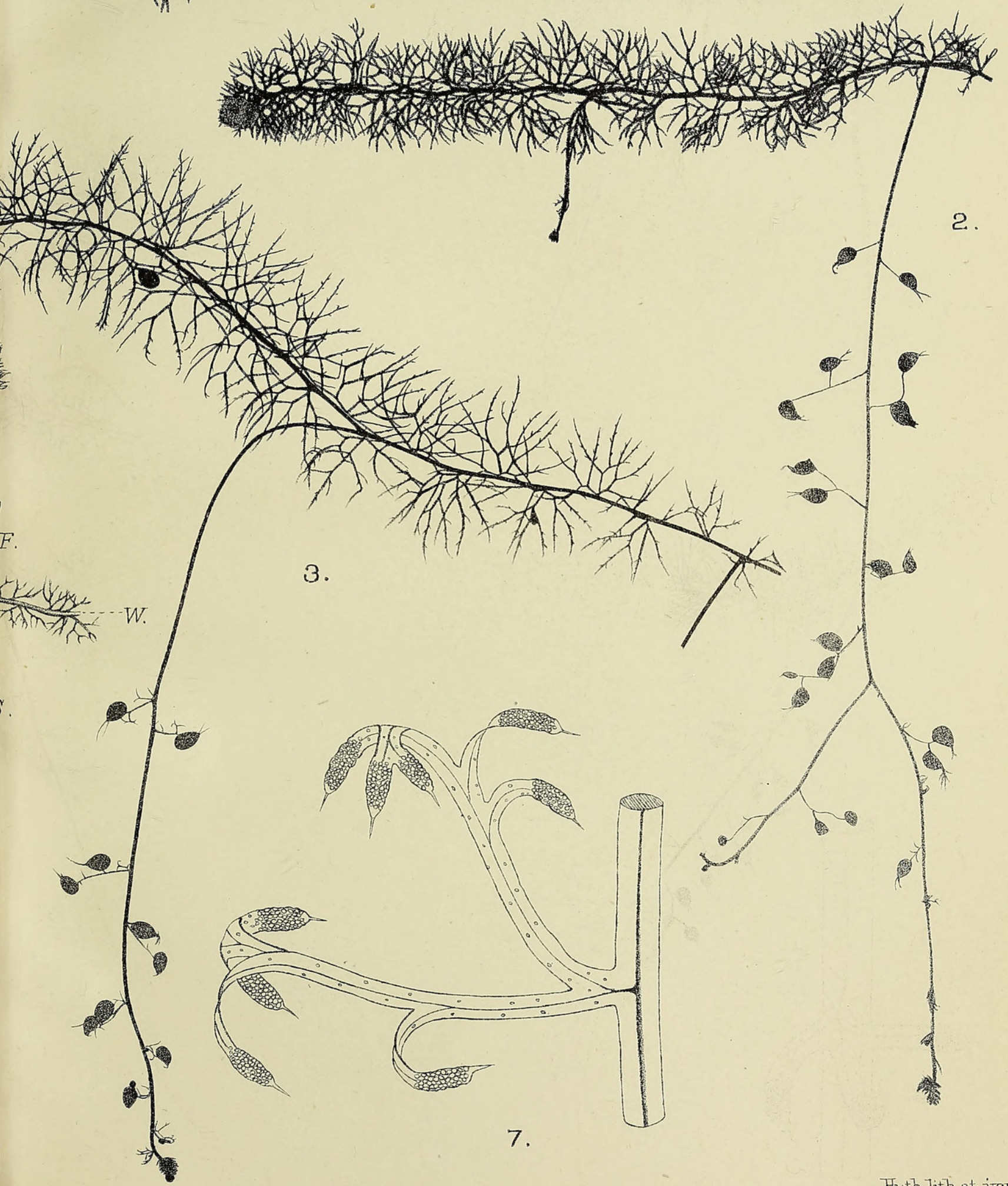




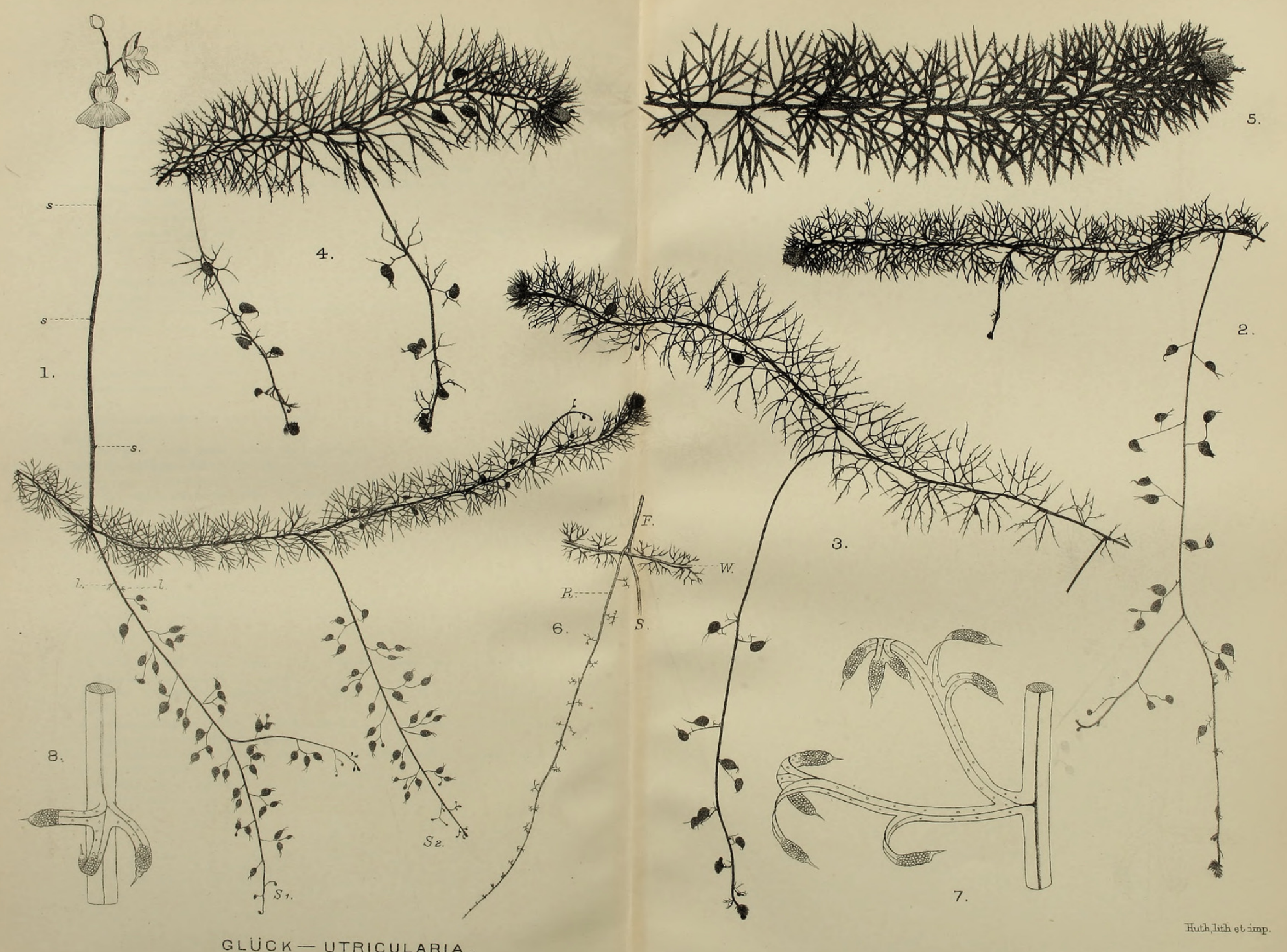


Annats of Botany,

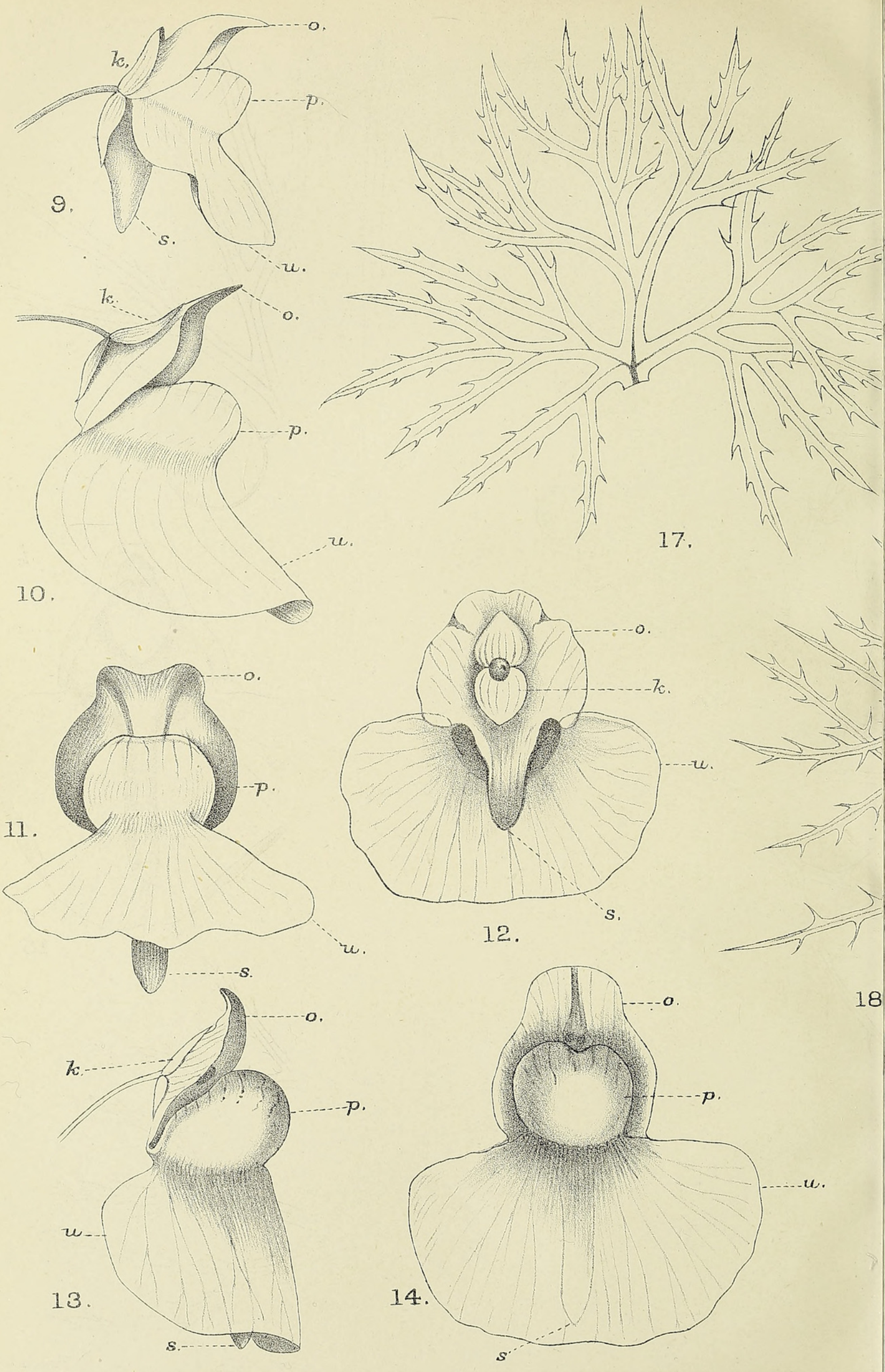

GLUCK-UTRICULARIA. 



\section{$2 \mathrm{BHL}$ Biodiversity Heritage Library}

Glück, Hugo. 1913. "Contributions to our knowledge of the species of Utricularia of Great Britain with special regard to the morphology and geographical distribution of Ytricularia ochroleuca." Annals of botany 27, 607-620. https://doi.org/10.1093/oxfordjournals.aob.a089479.

View This Item Online: https://www.biodiversitylibrary.org/item/237410

DOI: https://doi.org/10.1093/oxfordjournals.aob.a089479

Permalink: https://www.biodiversitylibrary.org/partpdf/319992

\section{Holding Institution}

Smithsonian Libraries

\section{Sponsored by}

Biodiversity Heritage Library

\section{Copyright \& Reuse}

Copyright Status: Not in copyright. The BHL knows of no copyright restrictions on this item.

This document was created from content at the Biodiversity Heritage Library, the world's largest open access digital library for biodiversity literature and archives. Visit BHL at https://www.biodiversitylibrary.org. 